R E S E N H A S

\title{
O MUNDO RURAL PARA ALÉM DO MUNDO AGRÍCOLA
}

Rural world beyond agriculture world

\author{
ANA ClÁUdia PinTO CORRÊA \\ Ruralidades contemporâneas: modos de viver \\ e pensar o rural na sociedade brasileira \\ Maria José Carneiro (CoOrd.) \\ Rio de Janeiro: Mauad X/ FAPERJ, 2012.
}

http://dx.doi.org/10.1590/S0103-21862015000200010

Ana Cláudia Pinto Corrêa é doutora em História Social pela PUC-SP, coordenadora de Pós-Graduação, Pesquisa e Extensão e professora dos cursos de Administração e Direito do Unifeg, e coordenadora da Pós-Graduação Lato-Sensu da PUC-Minas (Poços de Caldas) (anaclio@bol.com.br).

Resenha recebida em 30 de junho e aprovada para publicação em 13 de outubro de 2015. 
posição campo/cidade. Realidades sociais e espaciais descontínuas, ratificando a dicotomia existente entre elas. 0 mundo rural como inexoravelmente agrícola. 0 agricultor como o personagem encarregado de manter o "campo tradicional". Neste livro coordenado por Maria José Carneiro, esses paradigmas vão sendo quebrados, um a um, por meio da análise, principalmente, das experiências de agricultores e seus filhos, comerciantes, turistas, donos de pousadas ou confecções de localidades rurais (RJ, RS e MG). É pertinente, então, nos remetermos a Thompson (1981), para quem a experiência está no cerne da interpretação do processo histórico, ao tratar os sujeitos sociais como alguém que ajuda a tecer a teia da história e não apenas como seu mero espectador.

Dessa forma, ao longo de seus sete capítulos, os autores nos apresentam um locus rural em que a agricultura deixou de ser a atividade econômica fundamental no sustento familiar, o que não implica, necessariamente, o abandono da terra por seus donos, que se tornam pluriativos, ou seja, se valem de empregos - baixa qualificação e remuneração - em localidades próximas, que os ajudam a complementar sua renda mensal. Dificuldade de comunicação com mercados consumidores em potencial, dificuldade de transporte, ausência de uma política estatal agrícola eficiente e os preços baixos de seus produtos impulsionaram-nos a trabalhos outros. Esses problemas repercutem com mais profundidade nos jovens, que acabam por não se interessar em seguir o "tradicional" trabalho de seus pais. Além da questão econômica, eles tendem a considerar as ocupações não-agrícolas mais valorizadas simbolicamente.

A criação de signos ou a ressignificação dos já existentes, a necessidade de se incorporar o não material na esfera da produção também são destacadas. Nesse contexto, a natureza é o signo por excelência reelaborado e sobre o qual se constrói a nova noção de rural. Ela deixa de indicar um meio de produção e torna-se objeto de contemplação. A natureza assim entendida e visualizada passa a alimentar novas indústrias, quais sejam, a do turismo e a cultural. 0 foco, então, volta-se para a manutenção e recuperação do patrimônio rural (recursos naturais, bens arquitetônicos, festividades coletivas). Essa nova premissa da natureza, por sua vez, constitui-se em um dos recursos que viabilizam a pluriatividade referida anteriormente. Hotéis, pousadas, restaurantes, lojas, bares, entre outros, é que representam empregabilidade 
para membros de famílias tradicionalmente agrícolas, cuja sobrevivência é ameaçada pelos parcos recursos que essa atividade proporciona.

Por outro lado, a convivência entre sujeitos sociais e atividades díspares se faz presente no interior de um campo de forças tanto físico quanto simbólico. Para os agricultores, os organismos de proteção ambiental são vistos como autoritários, pois os obrigam a preservar uma área (mata) que poderia ser utilizada para a agricultura. Como agravante, essa situação provoca uma desvalorização da terra como bem de produção. No entanto, para os denominados neorrurais - que chegam por vezes a denunciar agricultores que derrubam a mata -, a natureza deve, de preferência, permanecer intocada, seja por seu senso ecológico, seja pela oportunidade em explorar o ecoturismo.

Cabe ressaltar que os agricultores geralmente se encontram em difícil situação econômica, ao passo que os novos residentes das localidades rurais, provenientes de centros urbanos maiores em busca da tranquilidade do campo quando, principalmente, de sua aposentadoria, são mais providos de capital. Por vezes também, possuem destacada voz ativa nas associações locais. Em algumas das áreas pesquisadas, as prefeituras promoveram melhorias como pavimentação de ruas, somente com a instalação daqueles moradores que, com seus estabelecimentos voltados para os turistas, contribuíram para a entrada de recursos nos cofres públicos.

É possível então vislumbrarmos, conforme defende Williams (1979), que o campo de forças no qual os atores sociais se "enfrentam" é permeado por uma cotidiana luta de classes na disputa por papéis hegemônicos nos espaços compartilhados. Variadas são as estratégias, inclusive simbólicas, utilizadas para se obter a referida hegemonia, uma vez que ela está constantemente se reconstruindo; nunca garantida. Entrevemos os neorresidentes respaldados pelo ethos ambientalista, sendo vistos como modernos e responsáveis quando o assunto é a natureza. Eles recebem apoio do poder público local e assumem posições de destaque em associações locais. Já os nativos (agricultores) são vistos como agressores do meio ambiente, atrasados ou até mesmo outsiders nas palavras dos autores, possuindo pouca inserção nas organizações locais. Talvez fosse o caso de nos perguntarmos se o que é tachado como agressão não poderia ser transmutado em resistência. Paradoxalmente, nessa ressignificação rural, em que há o desmonte do campo tradicional, verificamos o anseio pela manutenção da imagem do agricultor como alguém que, inexoravelmente, existe em função da terra e de seus frutos. Mais irônico ainda: essa valorização vem na esteira da constante presença de turistas da "cidade grande", que ainda se apoiam na figura lúdica do campo e do agricultor. É bem verdade que alguns agricultores, mesmo com as dificuldades apresentadas, preferem se manter exclusivamente no trabalho agrícola. 
Tomando como parâmetro o dizer dos autores, que seria mais apropriado substituir o conceito de êxodo rural pelo de êxodo agrícola, bem como o de famílias rurais pelo de famílias agrícolas, as palavras de Todorov (1999) fazem muito sentido, pois para ele toda cultura viva muda, ainda que nem todas as mudanças sejam boas. Um exemplo positivo está no agora ativo papel econômico das mulheres. De um modo geral, atuando por trás dos bastidores nos serviços domésticos e com sua invisibilidade sancionada, elas passam a vivenciar uma atuação direta no ganha-pão da família, mesmo que, incontestavelmente, a imagem de provedor continue apontando para seus maridos. Essa situação torna-se ainda mais perceptível em Laranjeiras - nome fictício de uma das localidades fluminenses pesquisadas -, que ganhou certo vigor a partir da instauração de confecções de lingerie que, em sua maioria, são abertas por mulheres que representam também a própria mão de obra.

Por fim, infere-se que a ruralidade está constantemente em reelaboração, adaptação e incorporação (ou não) às novas experiências vividas por seus atores sociais. Essas novas e imbricadas relações tornam as referências identitárias cada vez mais móveis. É pertinente nos remetermos a Bhabha (1998), para quem a nação é uma construção discursiva e não uma comunidade imaginada, homogênea e horizontal. Ele nos propõe observá-la como uma forma de vida híbrida, que apresenta suas fissuras e tensões. Assim, para os "de fora", o campo é pensado como uma realidade homogênea, cujos sujeitos são responsáveis por manter um modo de vida "autêntico", mas as observações feitas pelos autores nos levam a perceber identidades múltiplas entre os próprios agricultores, bem como entre esses e os neorrurais, homens e mulheres, agricultores e turistas, turistas e neorrurais. Portanto, é premente que fiquemos atentos à alteridade, uma vez que ela pode nos proteger da tentação de criarmos uma imagem única e modelar da identidade.

\section{REFERÊNCIAS BIBLIOGRÁFICAS}

BHABHA, Homi K. O local da cultura. Belo Horizonte: UFMG, 1998.

TODOROV, Tzvetan. O homem desenraizado. Rio de Janeiro: Record, 1999.

WILLIAMS, Raymond. Maxismo e literatura. Rio de Janeiro: Zahar, 1979. 